\title{
The Regulation of Corporate Tender Offers Under Federal Securities Law: A New Challenge for Rule 10b-5
}

The corporate tender offer, here defined as the corporation's offer to purchase its securities or those of another designated corporation from all $^{1}$ who tender those securities to the corporation for sale, has become increasingly popular in recent years ${ }^{2}$ for a variety of reasons. Some corporations apparently feel that during periods of market decline the low price of their shares makes purchases by the corporation desirable. ${ }^{3}$ Even under normal circumstances, corporations which need their own stock for such purposes as stock options or asset purchases may find the tender offer the most satisfactory method of obtaining their stock, 4 or one company may deem buying the shares of another corporation to be the most desirable means of taking over the other company. There also may be other less legitimate explanations for the corporation's purchase, as when it is done to secure management's control of the corporation. ${ }^{5}$

1 The New York Stock Exchange has requested that when a company is accepting only a specified number of shares, tenders be accepted on a pro rata basis for at least ten days, after which period acceptance may be on a "first come" basis. N.Y. STock Exchange, Company Manual A-180 (1963). North Carolina has attempted to assure the equal treatment of shareholders in each class by requiring pro rata purchases under some circumstances. N.C. GEN. STAT. \$ 55-52(c)(1) (1965).

2 See Fleck, Corporate Share Repurchasing: An Informal Discussion, Harv. Bus. S. Bull,, Jan.-Feb. 1965, p. 10; Merjos, Embracing Tenders: Wall Street Is Growing Increasingly Partial to Take-Over Bids, Barron's Nat'l Bus. \& Financial Weekly, March 6, 1961, p. 5. It has been estimated that in 1963 corporations spent $30 \%$ more purchasing their own common stock than they raised through equity issues. Fleck, supra at 10.

3 See Holt \& Morris, Some Aspects of Reacquired Stock, 1931-1933, 12 HaRv. Bus. REv. 505 (1934); Vartan, Why Companies Buy Own Shares, Christian Science Monitor, Jan. 18, 1963, p. I5, col. 1; Bargains Gone Begging?, Forbes, Nov. 1, 1962, p. 34.

4 A corporation may have other reasons for acquiring its own shares, such as to eliminate small holdings or to facilitate the sale of a large shareholder's stock. Fleck, supra note 2, at 11; Zilber, Corporate Tender Offers for Their Own Stock: Some Legal and Financial Considerations, 33 U. CiNc. L. REv. 315, 317-19 (1964). However, it would seem that alternative devices are available to the corporation in many situations in which the tender offer is utilized. For instance, shares for stock options or asset purchases can easily be obtained by issuing authorized but unissued shares or by authorizing additional shares. The main advantage of the tender method is that it eliminates the need to obtain shareholder approval of management's plans.

5 See Stevens, Corporations 279-80 (2d ed. 1949). 
To some extent state corporation and blue sky laws regulate tender offers, ${ }^{6}$ but recent cases indicate that federal securities law will provide the most effective weapon for challenging them. ${ }^{7}$ The applicability to tender offers of rule $10 \mathrm{~b}-5,{ }^{8}$ promulgated under section $10(\mathrm{~b})$ of the Securities Exchange Act, ${ }^{9}$ is part of the broader question whether the scope of rule 10b-5 should be expanded to develop a "federal corporation law" regulating corporate mismanagement generally or should be limited to cases of what is traditionally viewed as the purchase and sale of securities. ${ }^{10}$

6 Statutes in every state authorize corporations to purchase their own stock and set forth the limitations within which such purchases may be accomplished. See statutes listed in 1 Model Bus. Corp. Act ANN. § 5, đ 6 (1960, Supp. 1964). See generally Dodd, Purchase and Redemption by a Corporation of Its Own Shares, 89 U. PA. L. REV. 697 (1941); Kessler, Share Repurchases Under Modern Corporation Laws, 28 FordHAM L. REv. 637 (1960). The greatest barrier to effecting a corporate tender will often be found in the restrictions imposed by the contract rights of bondholders and preferred shareholders.

7 Section 10I of the Uniform Securities Act, the model for an increasing number of state blue sky laws, contains a provision identical to rule 10b-5, and most states which have not adopted the uniform act have similar antifraud provisions. See Loss \& CowErT, BLUE SKY LAw 250-51 (1958). However, although a defrauded buyer may sue under the uniform act, sellers' remedies are enforceable only by state administrators. UNIFORM SECURITIEs ACT $\S 410$. Such remedies afford sellers insufficient protection because administrators do not have adequate funds to prosecute all suits. See 3 Loss, Securitres Regulation 1631 (2d ed. 1961) [hereinafter cited as Loss].

817 C.F.R. § $240.10 \mathrm{~b}-5$ (1964):

It shall be unlawful for any person, directly or indirectly, by the use of any means or instrumentality of interstate commerce, or of the mails or of any facility of any national securities exchange,

(a) To employ any device, scheme, or artifice to defraud,

(b) To make any untrue statement of a material fact or to omit to state a material fact necessary in order to make the statements made, in the light of the circumstances under which they were made, not misleading, or

(c) To engage in any act, practice, or course of business which operates or would operate as a fraud or deceit upon any person, in connection with the purchase or sale of any security.

948 Stat. 891 (1934), 15 U.S.C. $\$ 78 \mathrm{j}(\mathrm{b})$ (1963): “Sec. 10. It shall be unlawful for any person, directly or indirectly, by the use of any means or instrumentality of interstate commerce or of the mails, or of any national securities exchange . . (b) to use or employ, in connection with the purchase or sale of any security registered on a national securities exchange or any security not so registered, any manipulative or deceptive device or contrivance in contravention of such rules and regulations as the Commission may prescribe as necessary or appropriate in the public interest or for the protection of investors."

Additional provisions of the securities acts may be applicable in certain circumstances. Section 9 of the Securities Exchange Act would apply if the corporation sold its shares on the exchange to lower the market price and the price which it would have to offer for tenders. 48 Stat. 889 (1934), I5 U.S.C. $\S 78 \mathrm{i}$ (1963). In a suit by the corporation as a purchaser, $\S 17$ of the act, whose provisions are similar to those of rule $10 \mathrm{~b}-5$, might be invoked. 48 Stat. 84 (1934), as amended, 15 U.S.C. $\$ 77 q$ (1963). If the corporation were to exchange stock which it held in other corporations for its own stock tendered to it, registration of the other corporation's stock might be required under the act and under state blue sky laws. See 48 Stat. 77 (1933), as amended, 15 U.S.C. \$ 77e (1963); UNIForM SECURITIES ACT § 301; Zilber, supra note 4, at 333-36; 1 Loss 182-84.

10 See Fleischer, "Federal Corporation Law": An Assessment, 78 HaRv. L. REv. 1146 
In general, two types of problems under rule $10 \mathrm{~b}-5$ may arise in connection with a corporate tender offer. The first involves the injury to the selling shareholder from the corporation's misrepresentation or nondisclosure of a material fact upon which he relied in deciding to sell. The second involves the insiders' use of the tender offer for personal profit or advantage. Such schemes may involve the tender of an insider's shares at an excessive price or the use of the tender to secure the insider's control of the corporation. This comment will explore the application of the disclosure provisions of rule $10 \mathrm{~b}-5$ to corporate tender offers by focusing on the standard of disclosure which that rule would appear to require in a tender offer and on the applicability of rule $10 \mathrm{~b}-5$ when an insider breaches his fiduciary duty to the corporation in connection with a tender offer. ${ }^{11}$

\section{The Applicability of Rule 10b-5 to Tender Offers for a Corporation's OWN SECURITIES}

Past applications of rule $10 \mathrm{~b}-5$ to misrepresentations, omissions, and fraud in connection with the purchase or sale of securities leave no doubt that tender transactions are within its scope; ${ }^{12}$ its provisions regarding insider trading and nondisclosure apply to corporate tender offers since the purchasing corporation possesses the ultimate in inside information. ${ }^{13}$ Furthermore, there is no longer any doubt that liability

(1965); Joseph, Civil Liability Under Rule 10b-5-A Reply, 59 Nw. U.L. REv. 171 (1964); Ruder, Pitfalls in the Development of a Federal Law of Corporations by Implication Through Rule 10b-5, 59 Nw. U.L. REv. 185 (1964); Ruder, Civil Liability Under Rule 10b-5: Judicial Revision of Legislative Intent?, 57 Nw. U.L. REv. 627 (1963); Comment, Civil Liability Under Section 10(b) and Rule 10b-5: A Suggestion for Replacing the Doctrine of Privity, 74 YALE L.J. 658, 680-82 (1965).

11 The discussion will deal primarily with the problems of publicly held corporations although much of it is applicable to close corporations as well. For a general treatment of purchases by close corporations, see 2 O'NeAl, Close Corporations 1-80 (1958).

12 See Kohler v. Kohler, 319 F.2d 634 (7th Cir. 1963) (dictum); Northern Trust Co. v. Essaness Theatres Corp., 103 F. Supp. 954 (N.D. Ill. 1952); Ward La France Truck Corp., 13 S.E.C. 373 (1943); 3 Loss 1453; Israels, Corporate Purchase of Its Own Shares-Are There New Overtones?, 50 CORNeLL L.Q. 620 (1965); Kennedy, Transactions by a Corporation in Its Own Shares, 19 Bus. LAw. 319 (1964). See generally S.E.C. Problems of Controlling STOCKHOLDERS AND IN UNDERWRITINGS 131-56 (Israels ed. 1962); Daum \& Phillips, The Implications of Cady, Roberts, 17 Bus. LAw. 939 (1962); Comment, Insider Liability Under Securities Exchange Act Rule 10b-5: The Cady, Roberts Doctrine, 30 U. CHI. L. REv. 121 (1962).

13 In Cady, Roberts \& Co., 40 S.E.C. 907, 912 (1961), the SEC explained the basis of the insider's liability: "Analytically, the obligation rests on two principal elements; first, the existence of a relationship giving access, directly or indirectly, to information intended to be available only for a corporate purpose and not for the personal benefit of anyone, and second, the inherent unfairness involved where a party takes advantage of such information knowing it is unavailable to those with whom he is dealing." 
under rule 10b-5 can arise in sales which are not made on a stock exchange, ${ }^{14}$ and that private parties may bring suit to enforce this liability even though neither section $10(\mathrm{~b})$ of the act nor rule $10 \mathrm{~b}-5$ mentions private enforcement. ${ }^{15}$ The reasoning of the Supreme Court in $J . I$. Case Co. v. Borak, ${ }^{16}$ which held that there was an implied private remedy under section $14(\mathrm{a})$ of the Securities Exchange Act ${ }^{17}$ for a violation of the proxy rules, applies as well to suits brought under rule $10 \mathrm{~b}-5^{18}$ and supports the argument that a tendering shareholder may challenge misrepresentations or omissions of fact made in connection with a corporation's offer to purchase. ${ }^{19}$

14 See, e.g., Matheson v. Armbrust, 284 F.2d 670 (9th Cir. 1960), cert. denied, 365 U.S. 870 (1961); Hooper v. Mountain States Sec. Corp., 282 F.2d 195 (5th Cir. 1960), cert. denied, 365 U.S. 814 (1961); Fratt v. Robinson, 203 F.2d 627 (9th Cir. 1953); Kardon v. National Gypsum Co., 73 F. Supp. 798 (E.D. Pa.), modified, 83 F. Supp. 613 (E.D. Pa. 1947); 3 Loss 1466-67.

Although the preamble to the Securities Exchange Act refers only to transactions "conducted upon securities exchanges and over-the-counter markets," Securities Exchange Act $\S 2$, 48 Stat. 88I (1934), 15 U.S.C. $\S 78 \mathrm{~b}$ (1963), judicial construction of $\S 10(\mathrm{~b})$ has emphasized the breadth of the section's language and the undesirability of exempting the numerous transactions which are private from the provisions of the act. See cases cited supra. It has been suggested that the $\S 10(\mathrm{~b})$ mandate to prescribe rules and regulations "in the public interest or for the protection of investors" indicates that Congress intended the scope of $\S 10(\mathrm{~b})$ to be broader than the preamble's language regarding exchanges suggests. Hooper v. Mountain States Sec. Corp., supra at 202; Latty, The Aggrieved Buyer or Seller or Holder of Shares in a Close Corporation Under the S.E.C. Statutes, 18 LAw \& Contemp. Prob. 505, 509-12 (1953). Some legislative history also suggests that Congress intended the term "over-the-counter market" to include all transactions not occurring on an exchange. See H.R. REP. No. 2307, 75th Cong., 3d Sess. 2 (1938). As construed, § 3(a)(10) of the Securities Exchange Act defines "security" to include instruments which could hardly be intended to be the subject of trading on exchanges or regular over-the-counter markets: the Supreme Court has construed the term "investment contract" to include a contract for the sale of citrus groves. SEC v. W. J. Howey Co., 328 U.S. 293 (1946).

15 See, e.g., Texas Continental Life Ins. Co. v. Dunne, 307 F.2d 242 (6th Cir. 1962); Hooper v. Mountain States Sec. Corp., supra note 14; Speed v. Transamerica Corp., 235 F.2d 369 (3d Cir. 1956); Fratt v. Robinson, supra note 14; Fischman v. Raytheon Mfg. Co., 188 F.2d 783 (2d Cir. 195I); Kohler v. Kohler Co., 319 F.2d 634 (7th Cir. 1963) (dictum); Boone v. Baugh, 308 F.2d 711 (8th Cir. 1962) (dictum); Comment, supra note 12, 30 U. CHI. L. REv. at 158-67; Comment, The Prospects for Rule X-10b-5: An Emerging Remedy for Defrauded Investors, 59 YaLE L.J. 1120, 1133-35 (1950). See generally Lowndes, Civil Liability Created by Criminal Legislation, 16 Mins. L. REv. 361 (1932); Thayer, Public Wrong and Private Action, 27 HARv. L. Rev. 317 (1914); Note, New Civil Liabilities Under Securities and Exchange Act Rules, 14 U. CHI. L. Rev. 471 (1947).

16377 U.S. 426 (1964).

1748 Stat. 895 (1934), 15 U.S.C. § 78n(a) (1963).

18 See Rogers v. Crown Stove Works, 236 F. Supp. 572, 573 (N.D. Ill. 1964), citing Borak for the proposition that a private remedy exists under rule $10 \mathrm{~b}-5$.

19 This comment is concerned mainly with actions brought by shareholders, even though the analysis applies equally well to injunctions sought by the SEC. Most litigation will probably arise from private suits since the SEC does not have the resources to scrutinize every tender offer. See J. I. Case Co. v. Borak, 377 U.S. 426, 432 (1964); Cary, Book Review, 
Both at common law ${ }^{20}$ and under rule $10 \mathrm{~b}-5^{21}$ the insiders' fiduciary duty to shareholders has been extended to impose a duty on the corporation which deals with its shareholders. The first application of rule $10 \mathrm{~b}-5$ after its promulgation was to a corporation which purchased its own shares without disclosing that it planned to resell the shares, that it would probably be liquidated, or that the corporation's financial position was vastly better than it had been in previous years. ${ }^{22}$ The directors who authorized the tender offer owned a large percentage of the company's outstanding shares. By having the corporation purchase the stock at a price artificially low because important information was not disclosed, they were able to obtain the same results as they would have by purchasing the stock for themselves on the market-they increased the percentage of total shares which they held and thus garnered a greater portion of the corporation's assets upon liquidation for less than that portion was worth-but without committing any of their own funds. Although the Securities and Exchange Commission's investigation resulted in a settlement between the corporation and its shareholders, the Commission's report was calculated to inform the business community that a corporation's use of inside information in this way violates rule $10 \mathrm{~b}-5 .^{23}$

Under rule 10b-5 the fiduciary duty of disclosure to those from whom the corporation purchases its stock may be breached by omissions to disclose material facts as well as by affirmative misrepresentations. At common law the majority rule probably did not require affirmative disclosures, ${ }^{24}$ but it is generally agreed that rule $10 \mathrm{~b}-5$ encompasses

75 HARv. L. REv. 857, 861 (1962). In cases of special importance the SEC might undertake the burden of litigation as it has in the recent action against the Texas Gulf Sulfur Corporation. SEC v. Texas Gulf Sulfur Corp., Civil No. 65-1182, S.D.N.Y., April 19, 1965; see Kennedy \& Wander, Texas Gulf Sulfur, A Most Unusual Case, 20 Bus. LAw, 1057 (1965). See also Comment, Recovery of Damages in Class Actions, 32 U. Cir. L. REv. 768, 784 (1965), suggesting that "the SEC could be given authority to act as a clearing house for information concerning pending suits by stockholders anywhere in the United States."

20 See Northern Trust Co. v. Essaness Theatres Corp., 348 Ill. App. 134, 108 N.E.2d 493 (1952); Wood v. McLean Drug Co., 266 IIl. App. 5 (1932); Steven v. Hale-Hass Corp., 249 Wis. 205, 231, 23 N.W.2d 620, 632 (1946) (dictum); 3 Loss 1454.

21 See authorities cited note 12 supra.

22 Ward La France Truck Corp., 13 S.E.C. 373 (1943).

$23 \mathrm{Id}$. at 374. Immediately after Ward La France, the SEC initiated other investigations involving the application of rule $10 \mathrm{~b}-5$ to corporate stock purchases which also failed to reach the litigation stage. SEC v. Boyd Transfer \& Storage Co., Civil No. 1548, D. Minn., Dec. 5, 1945 (consent decree), SEC Litigation Releases Nos. 295 (Aug. 20, 1945), 308 (Dec. 7, 1945); SEC v. Oils \& Indus., Civil No. 27-450, S.D.N.X., April 4, 1945 (dismissal on stipulation), SEC Litigation Release No. 224 (Sept. 29, 1944).

24 See Goodwin v. Agassiz, 283 Mass. 358, 186 N.E. 659 (1933); Peek v. Gurney, L.R. 6 H.L. 377 (1873). The minority view required affirmative disclosures. Seitz v. Frey, 152 Minn. 170, 174, 188 N.W. 266, 268 (1922); Note, 14 MiNN. L. REV. 530, 532 (1930). A compromise 
more than common law fraud. ${ }^{25}$ However, while rule $10 \mathrm{~b}-5$ does impose a duty to disclose on the corporation which buys or sells stock to its shareholders, this duty is not without certain limitations. One such limitation is that liability exists only where the undisclosed fact is "material"; another is that the nondisclosure must have actually caused the plaintiff's injury.

\section{A. Materiality}

Although courts disagree as to which clause of rule 10b-5 is violated by nondisclosure, ${ }^{26}$ it is clear that a purchasing corporation has a duty to disclose facts which "would materially affect the judgment of the other party to the transaction." 27 Courts have not defined "materiality" with much precision, and corporations offering to purchase have little to guide them. The lack of a workable definition leaves the purchasing corporation to decide at its peril what to disclose, knowing that a court at some later date may determine that it was wrong. ${ }^{28}$ But at least some

position required disclosure in "special circumstances." Strong v. Repide, 213 U.S. 419, 433-34 (1909). See generally Walker, The Duty of Disclosure by a Director Purchasing Stock From His Stockholders, 32 YALE L.J. 637 (1923). It has been argued that present rule 10b-5 doctrine is identical to the special circumstances rule. Ruder, Civil Liability Under Rule 10b-5: Judicial Revision of Legislative Intent?, 57 Nw. U.L. REv. 629, 670-71 (1963). But see Comment, supra note 12, 30 U. CHI. L. Rev. at 170.

25 E.g., Hooper v. Mountain States Sec. Corp., 282 F.2d 195 (5th Cir. 1960), cert. denied, 365 U.S. 814 (1961); List v. Fashion Park, Inc., 340 F.2d 457, 462 (2d Cir.) (dictum), cert. denied sub nom. List v. Lerner, 382 U.S. 811 (1965); Fry v. Schumaker, 83 F. Supp. 476 (E.D. Pa. 1947); cf. SEC v. Capital Gains Research Bureau, Inc., 375 U.S. 180 (1963); McClure v. Borne Chem. Co., 292 F.2d 824 (3d Cir.), cert. denied, 368 U.S. 939 (1961).

26 See List v. Fashion Park, Inc., supra note 25 (dictum) (violation of $\S 10 \mathrm{~b}-5(\mathrm{c})$ ); Speed v. Transamerica Corp., 99 F. Supp. 808 (D. Del. 1951) (violation of all three clauses); Joseph v. Farnsworth Radio \& Television Corp., 99 F. Supp. 701, 706 (S.D.N.Y. I95I), aff'd, 198 F.2d 883 (2d Cir. 1952) (violation of $\S 10 \mathrm{~b}-5$ (c)); Connelly v. Balkwill, 174 F. Supp. 49 (N.D. Ohio 1959) (dictum), aff'd per curiam, $279 \mathrm{~F} .2 \mathrm{~d} 685$ (6th Cir. 1960) (\$ 10b-5 to be read as a whole); Cady, Roberts \& Co., 40 S.E.C. 907 (1961) (a violation at least of clause (c)); Comment, Negligent Misrepresentations Under Rule 10b-5, 32 U. CHI. L. Rev. 824, 826-27 (1965). Since the tender offer usually is accompanied by a short statement of the corporation's financial condition, clause (b) will apply if additional facts are necessary to make these statements accurate. Because additional facts may be required even if the stated facts are not distorted, both clauses (a) and (c) may be pertinent.

27 Kardon v. National Gypsum Co., 73 F. Supp. 798, 800 (E.D. Pa. 1947).

28 The shareholder bringing suit will have the benefit of hindsight in viewing the transaction and utilizing discovery to examine documents which management may have considered unimportant at the time of the transaction. Courts should not permit plaintiffs to recover when the materiality of undisclosed facts became apparent only after the tender offer was made, since to do so would place an unfair burden on corporations. See Kennedy \& Wander, supra note 19, at 1067. Rather, courts should be concerned with determining whether the corporation failed to disclose facts which a reasonable man would have deemed material at the time of the transaction. Reliance on hindsight was properly rejected by one court which limited evidence to facts actually known by the directors at the time of 
guidelines may be found. As a bare minimum, the corporation should fully disclose its current earnings and the approximate market value per share of its assets. Also, unusual information which has a material bearing on the security's value, such as the anticipated sale of assets, should be disclosed.29

In Speed v. Transamerica Corp. ${ }^{30}$ the district court concluded that the failure to disclose the true value of inventory and management's intent to dispose of that inventory amounted to a fraudulent scheme violating all three clauses of rule $10 \mathrm{~b}-5$. Most nondisclosures will not involve facts so obviously material to the shareholder's decision to sell as those in Speed; facts concerning the usual course of business will often be "material" for rule $10 \mathrm{~b}-5$ purposes. Since at least in theory the corporation "knows" all facts relating to its affairs, this burden of disclosure may be difficult to meet. Hence, it might be argued that some limitation on what facts are material must be devised so the corporation's burden of disclosure will be tolerable. ${ }^{31}$

the transaction. Value Line Fund, Inc. v. Marcus, CGH FED. SEc. L. REP. I 91523 (S.D.N.Y. 1965).

The only cases in which the plaintiff has been required to prove that the directors were aware of the facts which they failed to disclose, however, have been those brought by purchasers, and the courts in those cases have been forced to reconcile liability under rule 10b-5 with that under $\S 12(2)$ of the Securities Act. Section 12(2) requires no proof of scienter and sets up a lack of knowledge as an affirmative defense. Some courts have imported a scienter requirement into purchasers' suits under rule $10 \mathrm{~b}-5$ to distinguish them from $\S 12(2)$ suits. See, e.g., Weber v. C.M.P. Corp., 242 F. Supp. 321 (S.D.N.Y. 1965); Trussell v. United Underwriters, Ltd., 228 F. Supp. 757 (D. Colo. 1964). But see, e.g., Ellis v. Carter, 291 F.2d 270 (9th Cir. 1961). In most suits brought by sellers, however, the issue has been ignored. E.g., Northern Trust Co. v. Essaness Theatres Corp., 103 F. Supp. 954 (N,D. III. 1952); Kardon v. National Gypsum Co., 69 F. Supp. 512 (E.D. Pa. 1946). At most it would appear that negligence must be established. See Kohler v. Kohler Co., 319 F.2d 634, 637 (7th Cir. 1963) (rejecting any requirement of knowledge or bad faith); Note, Proof of Scienter Necessary in a Private Suit Under SEC Anti-Fraud Rule 10b-5, 63 Mrcr. L. Rev. 1070 (1965); Comment, supra note 26, 32 U. CHr. L. Rev. 824; Comment, supra note 10,74 YALE L.J. 658.

29 One suggestion for determining what is a material fact for purposes of a registration statement and prospectus under $\$ 5$ of the 1933 Securities Act is that all facts necessary to cnable a calculation of value by a capitalization of future earnings should be disclosed. The "elements of risk" become the crucial facts, including the position of the corporation in its industry. Heller, Disclosure Requirements Under Federal Securities Regulation, 16 Bus. LAw, 300, 320 (1961). A similar approach might be feasible to determine what is material to a decision to sell.

3099 F. Supp. 808, 829 (D. Del. 1951).

31 Some commentators have predicted that various dire consequences would result from an expansion of disclosure requirements. See Kennedy \& Wander, supra note 19, at 1067; Ruder, supra note 10, 59 Nw. U.L. REv. at 208-14; Stigler, Public Regulation of the Securities Mrarkets, 19 Bus. Law. 721 (1964); Comment, supra note 10, 74 YALE L.J. at 689-90.

The burden of disclosure may be no greater under rule $10 \mathrm{~b}-5$ than the burden when the corporation offers its securities for sale. The prospectus and registration statement are required to include what are essentially all material facts. 68 Stat. 685 (1954), 15 U.S.C. 
The limitation should not, however, permit a corporation to refrain from disclosing information merely because it is available to the shareholder if he cares to examine the corporation's documents. ${ }^{32}$ Requiring a stockholder with no special expertise to search vast quantities of documents would permit the purchasing corporation effectively to evade its duty to disclose. Imposing this burden on the shareholder would be especially onerous if his security is not traded publicly since there would be no indication of its value other than that which a diligent search of all the corporation's records would suggest. Unusual circumstances, such as a proposed sale of assets, could intentionally be recorded in some obscure corporate document. A more reasonable approach might be to allow the corporation to rely on the disclosure of information in its reports to the SEC. These documents are open to public inspection and contain much of the normal business data necessary to evaluate securities. ${ }^{33}$ However, because many shareholders may not know that such information is available or may not be in a position to seek it out, the corporation should be required to disclose separately at least such "special information" as plans for the future. ${ }^{34}$ In fact be-

$\S 77 \mathrm{j}$ (1964); 48 Stat. 88 (1933), 15 U.S.C. $\$ 77$ aa (1964). The proxy rules also require information disclosing material facts. 17 C.F.R. $\$ 240.14 a-9$ (1964). Thus, the information which must be disclosed by the corporation issuing a tender offer may have already been compiled to meet the prospectus and registration or proxy requirements, in which case the only burden on the corporation at the time of the tender offer would be the expense of distributing the information to its stockholders.

32 But see Kohler v. Kohler Co., 319 F.2d 634 (7th Cir. 1963), awarding judgment for the corporation and relying partly on the fact that the seller, a former director, could have insisted that the corporation furnish him with the documents necessary to ascertain the value of his shares.

33 The 1964 amendments to the Securities Acts require that periodic reports be filed even by companies not listed on an exchange if they have total assets of one million dollars or more and have 750 holders of record of equity securities. After July 1, 1966, corporations with 500 shareholders also must file reports unless exempted by the SEC. SEC Securities Act Release No. 4725, Sept. 15, 1964.

New York Stock Exchange Rule 13(a)(13), form 9(k) requires semiannual reports of gross sales, operating revenues, net income, charges and credits to earned surplus, and extraordinary and special transactions. Rule $13(2)(11)$, form $8(k)$ requires that extraordinary acquisitions and dispositions of assets and specified changes in capital and control structure be reported within ten days after the close of a calendar month in which the actions take place. The New York Exchange also requires immediate reporting of dividend changes, redemptions, business purchases, and changes in officers and directors. NEw YORK STOCK Exchange, Company Manual, A-91-93 (1956), 94-104 (1959).

34 Some writers have argued that the SEC disclosure requirements discourage the misuse of insider information so much that any further requirement of disclosure by rule $10 \mathrm{~b}-5$ is unnecessary. Feuer, Personal Liability of Corporate Officers aind Directors 175 (1961). But the reporting requirement is an insufficient stimulus to full disclosure because an inadvertent deficiency in reports to the SEG does not occasion liability. In addition, the reports do not contain all material information. One court has pointed out that normally the information which the corporation does not want disclosed will not be found in the 
cause these "special facts" will usually be more important to the shareholder than information about the corporation's ordinary business, the most crucial problem regarding materiality concerns these unusual occurrences.

The recent case of List $v$. Fashion Park, Inc., ${ }^{35}$ involving a director's purchase of shares from a stockholder, raises by analogy the question of what plans for future actions must be disclosed by the purchasing corporation as material facts. In List the Second Circuit affirmed a finding that the directors' adoption of a resolution to sell the corporation was not a material fact, stating that disclosure would not have discouraged the shareholder from selling his shares since no profit was assured on the proposed sale of the corporation and in any case the possibility of sale was too remote to have influenced the conduct of a reasonable investor. ${ }^{36}$

The court's reasoning in List may be ingenuous. There is no question that information of a speculative nature, such as forecasts of market price, need not be divulged and may even provide a basis for a claim of misrepresentation if disclosed. ${ }^{37}$ But information which is so speculative that the reasonable investor will either find no value in it or will place undue emphasis on $\mathbf{i t}^{38}$ must be distinguished from facts which, when disclosed with adequate explanation, would probably influence substantially a rational investor's decision to tender. Negotiations to sell a corporation which reach the stage where a directors'

company's books and records. Kohler v. Kohler Co., 208 F. Supp. 808 (E.D. Wis. 1962), $a f f^{\prime} d, 319$ F.2d 634 (7th Cir. 1963). See Comment, supra note 15, 59 YALE L.J. at 1149.

35340 F.2d 457 (2d Gir.), cert. denied sub nom. List v. Lerner, 382 U.S. 811 (1965).

36 The court based its decision in part on James Blackstone Memorial Library Ass'n v. Gulf, M. \& O.R.R., 264 F.2d 445, 451 (7th Cir.), cert. denied, 361 U.S. 815 (1959), which held that only an "assured sale" could be a material fact, the "possibility of sale" being too remote to be material. The court in List ignored Ward La France Truck Corp., 13 S.E.C. 373,379 (1943), where the SEC concluded that the "considerable probability" that the corporation would be liquidated was sufficient to require disclosure. As an indication of the immateriality of the plan to sell, the List court also relied upon the defendant's selling $75 \%$ of his shares at a one dollar profit rather than holding for a larger profit when the corporation was subsequently sold. This fact, however, hardly supports a finding of immateriality as of the time the insider purchased the stock. The opinion is criticized in 37 CoLo. L. REv. 508 (1965).

37 It has been held that predictions of a market price increase will violate rule $10 \mathrm{~b}-5$ if there is no "reasonable basis in fact" for such predictions. SEC v. R. A. Holman \& Co., CCH FED. SEC. L. REP. If 91554 (S.D.N.Y. July 8, 1965). In Cady, Roberts, the SEC implied that information which was "a result of perceptive analysis of generally known facts" would be exempt from the disclosure requirement. 40 S.E.C. 907, 915 (1961).

38 Some common law cases suggest that an insider may have a fiduciary duty not to disclose his opinions where they will be given unduly authoritative weight by the shareholder. Tone v. Halsey, Stuart \& Co., 286 I11. App. I69, 3 N.E.2d 142 (1936); Sluss v. Brown-Crummer Inv. Co., 143 Kan. 14, 53 P.2d 900 (1936). 
resolution authorizes the sale are no longer too remote to be considered by shareholders contemplating tendering their shares even if a buyer for the corporation has not yet been found.

Although the decision in List may be difficult to justify, the notion of remoteness is useful. Intent is unquestionably a fact which must be disclosed by a purchaser. ${ }^{30}$ In Speed $v$. Transamerica Corp..${ }^{40}$ the court held that the intention to sell or liquidate the corporation in the future and to realize the gain from appreciated inventory was a material fact which should have been disclosed to the selling shareholder. It has even been held that one who, after the sale, violates an implied representation made at the time of the transaction is liable for failing to disclose his intention not to honor the implied representation. ${ }^{41}$ The critical distinction is between a firm intent to act in the future and mere discussion by management which has not resulted in a decision; the former is material and must be disclosed, the latter is not and need not be revealed. ${ }^{22}$ The remoteness of the action already taken in relation to the procedure needed for completing the transaction will determine whether the action is material. In a public corporation, the corporation's failure formally to record its decision might indicate that a final intention to act had not been formed. This lack of formality is less important in close corporations, and in any case would not be decisive where it could be shown that the corporation had decided to act but was attempting to conceal its decision.

The requirement to disclose all facts which would affect the shareholder's decision to sell poses another serious problem. Making public certain confidential information such as delicate merger negotiations or the development of a new and untested product might harm the

39 Ellis v. Carter, 291 F.2d 270 (9th Cir. 1961) (no intent at the time of the sale to keep a promise to share control); Keers \& Co. v. American Steel \& Pump Corp., 234 F. Supp. 201 (S.D.N.Y. 1964) (dictum) (breach of promise made at the time of sale); see 3 Loss 1469.

4099 F. Supp. 808 (D. Del. 1951).

41 United Funds, Inc. v. Carter Prods., Inc., CCH Fed. SEc. L. REp. f 91288 (Md. Cir. Ct. 1963); see Voege v. American Sumatra Tobacco Corp., 241 F. Supp. 369 (D. Del. 1965). But see Lester v. Preco Indus., Inc., CCH FED. SEC. L. REP. I 91562 (S.D.N.X. July 19, 1965) (refusing to consider the "evil intent" to injure in the future a fact which was not disclosed at the time of the transaction). Ruder, supra note 10,59 Nw. U.L. Rev. at 205-06, criticizes the extension of rule 10b-5 liability in such situations.

42 The New York Stock Exchange, Conpany Manual, A-19, 20 (1965), 21 (1962), sets forth the reasons for not disclosing certain plans for the corporation's future until a final decision has been made. Thereafter, timely disclosure is required, and the Exchange has requested corporate officials to disclose certain decisions, such as plans for mergers, stock splits, new contracts, products or discoveries, acquisitions, and changes in dividend rates or earnings. On the other hand, because management may countermand its decisions at the last minute, it has been suggested that it might be best not to require that such plans be disclosed. Daum \& Phillips, supra note 12, at 956-57. 
corporation. ${ }^{43}$ Yet the SEC in Cady, Roberts \& Co. stated bluntly that if material facts could not be revealed, the insider had no business in the market. ${ }^{44}$ This confronts the corporation with the difficult task of weighing the advantages of the purchase against the harm from the release of confidential information. ${ }^{45}$

It has also been said that materiality is defined in terms of the knowledge and "actual ... business acumen" of the particular shareholder who sues. ${ }^{46}$ Such a consideration might be relevant in the case of a close corporation with only a few dozen shareholders, but it is not helpful where a publicly held corporation is involved. A corporation would be required to employ primitive financial language to ensure that every shareholder could comprehend the data it was trying to communicate. Instead, the standard should be an objective one whereby material facts are those which "in reasonable and objective contemplation might affect the value of the corporation's stock or securities and which the insiders should reasonably believe are unknown to the outsider." 47 This standard would allow the corporation to send each share-

43 It would probably never be necessary to disclose the contents or formula of a trade secret, as the shareholder is satisfied with knowing merely that the company possesses a secret essential to a particular process.

44 S0 S.E.C. 907, 911 (1961); see Cary, Recent Developments in Securities Regulation, 63 Colum. L. Rev. 856, 864 (1963). In Van Alstyne, Noel \& Co., 33 S.E.C. 311 (1952), the Commission held that a broker-dealer who made misleading statements and failed to reveal material facts in selling a company's securities violated antifraud provisions notwithstanding his assertion that the information he concealed had been obtained from the company in confidence and could not be revealed. Id. at 320-21.

It might be thought that conflicting duties are placed on the director in that he has an obligation to the corporation to purchase the shares at the lowest possible price, while rule 10b-5 may make it necessary for him to disclose facts which will make it more costly for the corporation to purchase its shares than if that information were not disclosed. See Note, SEC Action Against Fraudulent Purchasers of Securities, 59 HARv. L. REv. 769, 77778 (1946). There is some indication that the director has a duty to purchase at as low a price as possible without committing common law fraud. See Bisbee v. Midland Linseed Prods. Co., 19 F.2d 24, 28 (8th Cir.), cert. denied, 275 U.S. 564 (1927); Note, Fiduciary Duty of Officers and Directors Not To Compete with the Corporation, 54 HARv. L. REv. 1191, 1196 (1941). No court, however, could hold a director to a duty which would require him to violate rule 10b-5 since federal law overrides conflicting provisions of local law. U.S. CoNST. art. VI; Gibbons v. Ogden, 22 U.S. (9 Wheat.) 210 (1824); see Comment, supra note 12, 30 U. CHI. L. REv. at 155-58.

45 The dilemma which might face a corporation is illustrated in the pending SEC action against Texas Gulf Sulfur Corporation. The discovery of a high grade copper and zinc deposit was concealed from the public while insiders bought the corporation's stock on the market. If the corporation had disclosed its discovery at an earlier time, it would have been much more difficult, if not impossible, to purchase the land and mineral rights in the vicinity of the original discovery. SEC v. Texas Gulf Sulfur Corp., Civil No. 65-1182, S.D.N.Y., April 19, 1965. See Kennedy \& Wander, supra note 19.

46 See Kohler v. Kohler Co., 319 F.2d 634, 641-42 (7th Cir. 1963).

47 Id. at 642; cf. Shvetz v. Industrial Rayon Corp., 212 F. Supp. 308 (S.D.N.Y. 1960), 
holder the same information at the time of the tender offer and would impose a practical limit on the quantity of information which need be disclosed.

\section{B. Reliance}

Materiality should not be confused with reliance, another limitation on the insiders' duty of disclosure under rule $10 \mathrm{~b}-5 .{ }^{48}$ In List $v$. Fashion Park, Inc. ${ }^{49}$ the Second Circuit affirmed the dismissal of a suit because the buyer's failure to disclose that he was an insider was not relied upon by the plaintiff in deciding to sell. Although the Second Circuit's choice of the term "reliance" in this context is somewhat misleading, since a more accurate statement of the concept would be that liability should not be imposed if the corporation's failure to disclose did not cause the plaintiff's injury, other courts have utilized the term in finding that the insider may be exculpated if disclosure of the true facts would not have convinced the plaintiff to refrain from selling. ${ }^{50}$ This applica-

holding that a corporation need not explain the ramifications of a proxy solicitation in elementary terms understandable to every layman. Rule 405, promulgated under the registration provisions of the Securities Act, defines "material" to include "those matters as to which an average prudent investor ought reasonably to be informed before purchasing the security registered." I7 C.F.R. \$ 230.405(1) (1964).

In discussing the common law action of fraud in sales, $\S 538(2)$ (a), RESTATEMENT, Torts (1934), defines "materiality" in terms of whether "a reasonable man would attach importance [to the fact misrepresented] in determining his choice of action in the transaction in question." Accord, 1 Harper \& James, Torts 565-66 (1956); Prosser, Torts 554-55 (2d ed. 1955). This definition was accepted by the court in List v. Fashion Park, Inc., 340 F.2d 457 (2d Gir.), cert. denied sub nom. List v. Lerner, 382 U.S. 811 (1965). The court indicated that this test was to be distinguished from the test of reliance which is unique to each plaintiff. Id. at 463 .

It should be noted that the court in Kohler utilized the selling shareholder's "actual ... business acumen" to absolve the corporation from any obligation to disclose data in terms that the most ignorant investor could understand. The plaintiff in Kohler was a former director with formidable financial experience. In these terms, the Kohler approach makes sense: the corporation must disclose only that which the ordinary investor would find necessary to an informed judgment; yet if it fails to do so, a specially expert plaintiff will still be foreclosed from suing because he did not reasonably rely on the corporation's failure to disclose. But this is really a statement of the reliance factor which is a limitation on the corporation's liability for nondisclosure in addition to and distinct from materiality.

48 E.g., List v. Fashion Park, Inc., supra note 47, at 462-64. By analogy to $\$ 12(2)$ of the Securities Act, it might be argued that proof of injury is an additional limitation on shareholder suits. In Mott v. Tri-Continental Financial Corp., 330 F.2d 468 (2d Cir. 1964), the plaintiff resold the securities for the same price he paid and was not permitted under $\$ 12(2)$ of the Securities Act to sue for either damages or rescission.

49340 F.2d 457 (2d Cir.), cert. denied sub nom. List v. Lerner, 382 U.S. 811 (1965).

50 Reed v. Riddle Airlines, 266 F.2d 314, 317 (5th Cir. 1959); Smith v. Bear, 237 F.2d 79, 88 (2d Cir. 1956); Baird v. Franklin, 141 F.2d 238, 239 (2d Cir.), cert. denied, 323 U.S. 737 (1944); Carr v. Warner, 137 F. Supp. 611, 615 (D. Mass. 1955); Mills v. Sarjem Corp., I33 F. Supp. 753, 767 (D.N.J. 1955); see Painter, Inside Information: Growing Pains for 
tion of the rule $10 \mathrm{~b}-5$ reliance principle is proper since in cases of misrepresentation a statement which is not relied upon is not a basis for compensation because it does not cause the plaintiff's injury. ${ }^{51}$ This requirement necessitates an examination of the state of mind of each plaintiff in the light of his own financial expertise and knowledge of the corporation's affairs as well as of the information disclosed to him by the corporation. ${ }^{52}$ The shareholder's financial sophistication would then tend to vitiate the corporation's liability to him; but the extraordinary ignorance of a particular shareholder would not expand the corporation's liability because such liability exists only for material omissions, those which the reasonable investor would have found useful. ${ }^{53}$

\section{Director's Actual Knowledge}

This discussion has presupposed that all material facts are known to at least some of the insiders who are responsible for the tender offer. The corporation purchasing stock could then be held liable for the knowledge of its agents. However, the limits placed on the information which the corporation is obliged to divulge should take into account the fact that the officers and directors of a large corporation cannot be acquainted with all of the company's affairs. To do so would not unduly limit the scope of rule $10 \mathrm{~b}-5$ since its purpose is to prevent the utilization of inside information to the detriment of the uninformed. ${ }^{54}$ "Where unawareness of the undisclosed facts on the part of those authorizing the tender offer is reasonable, the corporation should not be liable under rule $10 \mathrm{~b}-5$ because this is one of the risks of investing

the Development of Federal Corporation Law Under Rule 10b-5, 65 CoLuM. L. REv. I361, 1366-72 (1965).

51 See Mott v. Tri-Continental Financial Corp., 330 F.2d 468 (2d Cir. 1964).

52 Once the shareholder has established the materiality of the fact omitted or misrepresented, it might be best to give him the benefit of a presumption that he in fact relied upon the misrepresentation or that the omission caused his injury. This presumption would be justified by the difficulty of proving reliance and the probability that shareholders will rely upon representations made by the corporation. In Janigan v. Taylor, 344 F.2d 781 (lst Cir.), cert. denied, 382 U.S. 879 (1965), the court of appeals applied such a presumption and rejected the defendant's claim that the district court had not found that the plaintiff relied upon the misrepresentation. The court, referring to the relationship of trust between the shareholder and defendant insider, held that a finding of reliance was implicit in the lower court's decision. Even if other courts do not adopt this approach, the burden of going forward will probably shift to the defendant once the plaintiff testifies that he relied upon the misrepresentation, requiring the defendant to furnish proof of nonreliance if the plaintiff's testimony is believed.

53 In a suit by more than one shareholder, the distinction between materiality and reliance would be important. Even if the undisclosed facts were proved to be material, one plaintiff might recover and the other not if the nondisclosure caused the first to sell but was irrelevant to the decision of the second.

54 See Speed v. Transamerica Corp., 99 F. Supp. 808, 829 (D. Del. 1951); Cady, Roberts \&: Co., 40 S.E.C. 907,912 (1961). 
which the shareholder must bear. This standard should amply protect the shareholder if the insider has the burden of proving both that he was actually unaware of a fact so important that it materially affects the security's value and that this unawareness was reasonable.55 $V$

If one of the insiders for his personal gain should deliberately conceal the existence of a material fact from the rest of those authorizing the tender offer, the corporation should probably still be liable for the nondisclosure. The other directors should reasonably be expected to know most information which one insider might learn and which would be material to shareholders. In any case the corporation should bear the risk since it is in a better position to detect the fraud and should be responsible for the knowledge of its directors on something akin to principles of agency. ${ }^{56}$ Where the remedy granted for a violation of rule $10 \mathrm{~b}-5$ is rescission of the transaction the corporation may be in no worse position than before the transaction. ${ }^{57}$ The company should also be permitted to recover against the deceiving director. ${ }^{58}$

55 Several cases dealing with the antifraud provisions of the Securities Act seem to apply a "due diligence" standard and imply that the insider must make reasonable efforts to ascertain important facts. Stone v. United States, 113 F.2d 70, 75 (6th Cir. 1940); Alexander Reid \& Co., SEC Securities Act Release No. 6727 (Feb. 8, 1962); see 3 Loss 1440; Comment, supra note 15, 59 YALE L.J. at 1148. State corporation law imposes a similar duty upon directors to inform themselves about the business affairs of the corporation, at least to the extent that they be able to vote intelligently at board meetings. See, e.g., Bates v. Dresser, 251 U.S. 524 (1920); Barnes v. Andrews, 298 Fed. 614 (S.D.N.Y. 1924); Ballantine, CorporaTIONs \$§ 62, 63 (rev. ed. 1946); Douglas, Directors Who Do Not Direct, 47 HaRv. L. REv. 1305 (1934). It is arguable that the ignorance of a director who is not informed to the extent required by his duty is not reasonable. In any case, the duty imposed by state law probably does not encompass all facts which would be material if undisclosed to a selling shareholder under rule $10 \mathrm{~b}-5$.

50 If the directors can be considered agents of the corporation for purposes of tender offers, the corporation might be held for their torts when they act within the scope of their authority and "ostensible authority." E.g., Paul H. Aschkar \& Co. v. Kamen \& Co., CCH Fed. SEc. L. REP. If 91565 (S.D. Cal. 1964); Hawkins v. Merrill, Lynch, Pierce, Fenner \& Beane, 85 F. Supp. 104 (W.D. Ark. 1949) (indicating that the corporation may be a "controlling person" responsible for its agents' violations of the securities acts).

57 Loss suggests that the plaintiff may elect rescission or damages. 3 Loss 1792-94. The exact measure of damages in a suit under rule $10 \mathrm{~b}-5$ is not clear since few reported cases discuss this issue. Recently in Janigan v. Taylor, 344 F.2d 781 (1st Cir.), cert. denied, 382 U.S. 879 (1965), the court held the purchaser who failed to disclose a material fact liable not only for the difference between the value of the securities at the time of the sale and the amount paid by the plaintiff, but also for the amount by which the value increased after the transaction. Thus, the plaintiff received not only the amount he lost at the time of the sale, but also the amount which he would have received had he kept the stock. An accounting for profits appears to be the general rule. Kardon v. National Gypsum Co., 73 F. Supp. 798 (E.D. Pa.), modified, 83 F. Supp. 613 (E.D. Pa. 1947); 3 Loss 1793-94. Although rescission would ordinarily not harm the corporation, it might be difficult for the corporation to return the stock if it had been used for a merger, acquisition of assets, or similar transaction, except by authorizing and issuing new shares.

58 Under $\S 410(\mathrm{~b})$, UNIFORM SECURITIES AcT, enacted in twenty states, all directors are 


\section{The Applicability of Rule 10b-5 to Tender Offers for Securities of Another Corporation}

The increasing popularity of the tender offer as a device by which one corporation seeks to acquire control of another by offering to buy all of its shares which are tendered for sale at a stipulated price ${ }^{59}$ raises the problem of whether the limits of the rule 10b-5 duty to disclose in such "take-over bid" situations are identical to those imposed when a corporation offers to purchase its own stock. It is not clear that a duty to disclose exists at all, even though rule 10b-5 literally applies to "any person." Both at common law ${ }^{60}$ and under rule $10 \mathrm{~b}-5^{61}$ a fiduciary duty to a shareholder has been required before a duty to disclose will be found. If the purchasing corporation is already a controlling shareholder in the second corporation, a fiduciary duty exists since a controlling shareholder is considered an insider in his relations with minority shareholders. ${ }^{62}$ The existence of a similar duty is more difficult to establish where the purchasing corporation has only a small interest or none at all in the second corporation at the time it makes the tender offer.

There is reason to believe that the purchasing corporation has no duty of disclosure ${ }^{63}$ except when it obtains material facts from an in-

liable for the corporation's misrepresentation unless they can affirmatively prove their lack of knowledge concerning the misrepresentation. At common law a director, who is deemed to be a trustee for the corporation whose assets constitute the trust corpus, might be held liable if he allowed other directors to profit at the corporation's expense. Cf. Mosser v. Darrow, 341 U.S. 267, 272 (1951).

Under the Securities Exchange Act all "controlling persons" are jointly liable unless they establish that they acted in good faith and did not induce the act constituting the violation. 48 Stat. 899 (1934), 15 U.S.C. $\$ 78 t$ (1964). It appears that "control" requires more than merely serving on the board of directors and liability will probably be attributed only when the defendant should have known of the violation and could have prevented it. See 3 Loss 1808-11; cf. Hawkins v. Merrill, Lynch, Pierce, Fenner \& Beane, 85 F. Supp. 104 (W.D. Ark. 1949).

59 See Merjos, Embracing Tenders: Wall Street Is Growing Increasingly Partial to TakeOver Bids, Barron's Nat'l Bus. \& Financial Weekly, March 6, 1961, p. 5; Cash Is Eclipsing Proxy Wars, N.Y. Times, Jan. 17, 1966, p. 110, col. 3. This device is more properly called a take-over bid than a tender offer.

60 E.g., Strong v. Repide, 213 U.S. 419, 431 (1909); Carpenter v. Danforth, 52 Barb. 581 (N.Y. 1868).

61 E.g., Connelly v. Balkwill, 174 F. Supp. 49 (N.D. Ohio 1959), aff'd per curiam, 279 F.2d 685 (6th Cir. 1960); Mills v. Sarjem Corp., 133 F. Supp. 753 (D.N.J. 1955); see Painter, supra note 50 , at $1383-84$.

62 James Blackstone Memorial Library Ass'n v. Gulf, M. \& O.R.R., 264 F.2d 445 (7th Cir.), cert. denied, 361 U.S. 815 (1959); Speed v. Transamerica Corp., 99 F. Supp. 808 (D. Del. 1951). Few cases at common law considered the fiduciary status of controlling shareholders. 3 Loss 1446 n.4; see Comment, Insider Liability Under Securities Exchange Act Rule 10b-5: The Cady, Roberts Doctrine, 30 U. CHI. L. REv. 121, 131 n.51 (1962). The shareholder who is able to control without majority ownership should be considered an insider since insider liability is based on the ability to command inside information.

63 Connelly v. Balkwill, 174 F. Supp. 49 (N.D. Ohio 1959), aff'd per curiam, 279 F.2d 685 
sider in the second corporation. Cady, Roberts \& Co. suggests that the recipient of information from an insider, although not an insider himself, is equally obligated to disclose. ${ }^{64}$ Agency theories, analogous to the "relationship" with an insider found in Cady, Roberts, have been invoked at common law to impose liability on the purchaser who gains information from an insider. ${ }^{65}$ In large part, horvever, these authorities hold the purchaser responsible to the corporation, the beneficiary of the constructive trust imposed on the purchaser who acts with inside information. ${ }^{66}$

Information which is obtained in the course of business relations and which is not publicly known may transform the recipient into an insider. ${ }^{67}$ Thus, when insiders of the second corporation share inside information with those who seek to purchase their corporation, the purchasers should also be considered insiders. The only reason for limiting Cady, Roberts is to protect from liability those who receive

(6th Cir. 1960); Mills v. Sarjem Corp., I33 F. Supp. 753 (D.N.J. 1955); see 3 Loss 1434. The court in Mills held that even if the corporation obtained over $50 \%$ of the stock it would not be forced to disclose information gained while it was still an outsider. This position is untenable unless the policy behind rule 10b-5 extends only to those who are in a fiduciary relationship when the information is received, and Cady, Roberts \& Co., 40 S.E.C. 907 (1961), casts considerable doubt on such an assumption.

6440 S.E.C. 907 (1961). The SEC noted that rule 10b-5 literally applies to "any person" and "thus our task here is to identify those persons who are in a special relationship with a company and privy to its internal affairs, and thereby suffer correlative duties in trading in its securities." Id. at 912. The Commission relied on $\S 201(2)$, Restatement, RestrtuTION (1937): "Where a fiduciary in violation of his duty to the beneficiary communicates confidential information to a third person, the third person, if he had notice of the violation of duty, holds upon a constructive trust for the beneficiary any profit which he makes through the use of such information." In the private litigation resulting from the recent SEC action against Texas Gulf Sulfur Corporation, supra note 45, the courts will be required to determine how far the "relationship" discussed in Cady, Roberts extends, since many purchasers of shares were not insiders but had received tips to buy without realizing the confidential nature of the information. See Kennedy \& Wander, Texas Gulf Sulfur, $A$ Most Unusual Case, 20 Bus. LAw. 1057 (1965).

65 In re Frazin \& Oppenheim, 181 Fed. 307, 311 (2d Cir. 1910); Restatement, Agency $\S \S 85,272$ (1933); 3 Loss 1450; Comment, supra note 62, 30 U. CHI. L. REv. at 145-47; cf. Blau v. Lehman, 368 U.S. 403,410 (1962).

66 See Brophy v. Cities Serv. Co., 31 Del. Ch. 241, 70 A.2d 5 (Ch. 1949), holding an employee who purchased his employer corporation's stock on the open market on the basis of secret information obtained at work liable to the corporation for his profits even though no loss to the corporation was shown. In some cases the insider-fiduciary may be liable for profits made by third persons with whom he shares no financial interest. See Mosser v. Darrow, 341 U.S. 267, 272 (1951).

67 Hughes \& Treat, 22 S.E.C. 623 (1946); Note, 39 CaLrF. L. REv. 429, 434 (1951); Comment, The Prospects for Rule X-10b-5: An Emerging Remedy for Defrauded Investors, 59 YALE L.J. 1120, 1134 (1950). A broker inducing a corporate employee to transmit information to him was held liable to a purchaser under rule 10b-5, although his liability may be explained by the special duties of a broker. Herbert L. Honohan, 13 S.E.C. 754 (1943). 
information without being aware of its confidential nature. ${ }^{68}$ It is improbable that a purchasing corporation with inside information will be an "innocent party" deserving protection; more likely, it will have deliberately attempted to learn as much as possible about the company before issuing the tender offer. Even if the purchasing corporation does not encourage the insider to reveal the information, it may be aware that disclosures to it involved a breach of trust. ${ }^{69}$

Although the corporation purchasing its own shares is properly deemed to know all material facts about its own operations, the likelihood that it will have the same knowledge when purchasing stock of another corporation is not nearly so great. Therefore, it should be presumed that the purchasing corporation had no knowledge of any inside information concerning the second company. Such a presumption of arm's-length dealing would, however, be destroyed if nondisclosure or misrepresentation of a material fact and some degree of inside knowledge of the purchased corporation are shown, with the burden shifting to the purchaser to prove that it did not know the fact.

An important difference between the facts which must be disclosed by the corporation purchasing its own stock and the corporation seeking to take over another company by purchasing its stock is that the former must disclose its firm plans for future actions-these constitute inside information-while the latter need not, since its plans are not the plans of insiders until it becomes the controlling shareholder. ${ }^{70}$

68 See 3 Loss 1451; Painter, supra note 50, at 1389; Note, 39 CALIF. L. Rev. 429, 438-39 (1951). Each commentator advocates following § 201(2), REstateNENT, Restrrution (1937), quoted supra note 64 , by requiring disclosure by those who receive insiders' "tips" and know that they constitute a breach of trust. The common law cases applying this rule of disclosure to outsiders involved a relationship between the insider and outsider which went beyond the mere transmission of information. The outsider either induced the insider to procure the information, obtained the information as a result of an employment relationship, or traded with the tacit consent of the insider who knew of the transaction and was in a position to control it. See Comment, supra note 62, 30 U. CHI. L. REv. at 125-30. This may explain the statement in Cady, Roberts respecting the "existence of a relationship" there. The insistence on proof of some sort of bilateral relationship would guard against entrapping the innocent investor. See Ruder, Civil Liability Under Rule 10b-5: Judicial Revision of Legislative Intent?, 57 Nw. U.L. REv. 627, 669-70 (1963). Ruder has suggested elsewhere that the trend of the cases indicates that all persons possessing inside information, no matter how obtained, may now have a duty of disclosure. Ruder, Pitfalls in the Development of a Federal Law of Corporations by Implication Through Rule 10b-5, 59 Nw. U.L. REv. 185, 194 (1964).

69 In neither Connelly v. Balkwill, 174 F. Supp. 49 (N.D. Ohio 1959), aff'd per curiam, 279 F.2d 685 (6th Cir. 1960), nor Mills v. Sarjem Corp., 133 F. Supp. 753 (D.N.J. 1955), where the courts held that no fiduciary duty existed between the plaintiff and defendant, did the insider give confidential information to the defendant. Hence, these cases are not inconsistent with requiring a purchasing corporation to disclose information obtained from insiders of the second corporation.

70 Cf. Mills v. Sarjem Corp., 133 F. Supp. 753 (D.N.J. 1955). 


\section{Application of Rule 10b-5 to Insiders' Self-Dealing}

When directors or other insiders manipulate the tender offer to their advantage, they violate their fiduciary duty to the corporation. This constitutes a cause of action under state law. ${ }^{71}$ Rule $10 \mathrm{~b}-5$ may also be a basis for relief against such self-dealing insiders.

The most frequent scheme whereby the insider employs deception in the tender offer to benefit himself at the expense of the corporation is to set the tender offer price much higher than the fair value and to tender his own stock. He will probably be willing to allow the others who tender to share in the looting of the corporate treasury. If he can sufficiently confuse or deceive the remaining shareholders into thinking that the price is not exorbitant, the insider can reap a large gain. He might even cause the corporation to bid up the market price for its securities by purchases before making the tender offer, thus causing the tender price to appear more equitable. ${ }^{72}$

Judge Augustus Hand pointed out that a breach of fiduciary duty does not necessarily involve liability under rule 10b-5. In Birnbaum v. Newport Steel Corp..${ }^{73}$ recovery was denied in a derivative suit which alleged that the sale of the insider-defendant's controlling shares in the corporation to a third person constituted fraud upon the corporation. The Second Circuit held that rule 10b-5 did not apply because it was directed only at the type of fraudulent practice or misrepresentation "usually associated with the sale or purchase of securities rather than at fraudulent mismanagement." 74 This is not to say, however, that fraudulent mismanagement or acts in breach of a fiduciary duty cannot constitute a violation of rule $10 \mathrm{~b}-5$; it is just that such mismanagement must be "usually associated with the sale or purchase of securities."75

\section{A. An Insider's Deception in Tendering His Stock}

It can be argued that rule $10 \mathrm{~b}-5$ is not applicable to an insider's sale of stock to the corporation at an excessive price because the sale

71 See, e.g., Dixmoor Golf Club v. Evans, 325 Ill. 612, 156 N.E. 785 (1927); Ross Transp. v. Crothers, 185 Md. 573, 45 A.2d 267 (1946); Restatement (SECOND), Agency § 390 (1958); Rohrlich \& Rohrlich, Psychological Foundations for the Fiduciary Concept in Corporation Law, 38 Colum. L. Rev. 432 (1938); Uhlman, The Legal Status of Corporate Directors, 19 B.U.L. REv. 12 (1939).

72 The income tax aspects of corporate distributions are of great importance to the insider who attempts to appropriate a large part of the corporation's surplus by tendering his shares. For a discussion of these problems, see Zilber, Corporate Tender Offers for Their Own Stock: Some Legal and Financial Considerations, 33 U. CINc. L. Rev. 315, 35666 (1964).

73193 F.2d 461 (2d Cir.), cert. denied, 343 U.S. 956 (1952).

74 Id. at 464.

75 Acts which violate state corporation laws may also involve liability under rule 10b-5. 
constitutes no more than a breach of a fiduciary duty and mismanagement of the internal affairs of the corporation. ${ }^{70}$ The Securities Exchange Act demonstrates concern "for the protection of investors" trading with those possessing inside knowledge respecting the value of securities, ${ }^{77}$ and arguably the corporation purchasing its own securities does not fall within the protection of the act because it is not an "investor." However, this view has been rejected because courts have broadly construed the securities acts to effectuate their purpose of protecting investors. ${ }^{78}$ This approach would appear justified in the case of a tender offer since an investor, the nontendering shareholder, is injured by the loss which the corporation suffers when it purchases its stock at an inflated price. ${ }^{79}$

Relief under the Securities Exchange Act is "in addition to any and all other rights." 48 Stat. 903 (1934), 15 U.S.C. $\$ 78 \mathrm{bb}$ (1964).

70 See Comment, Civil Liability Under Section $10 B$ and Rule 10B-5: A Suggestion for Replacing the Doctrine of Privity, 74 YAle L.J. 658, 681-82 (1965).

77 Section 10(b) of the Securities Exchange Act authorizes the SEC to promulgate necessary rules "in the public interest or for the protection of investors." 48 Stat. 891 (1934), 15 U.S.C. $\$ 78 \mathrm{j}(\mathrm{b})(1964)$.

78 In Hooper v. Mountain States Sec. Corp., 282 F.2d 195 (5th Cir. 1960), cert. denied, 365 U.S. 814 (1961), the court noted that \$10(b) also included those offenses which must be prevented "in the public interest," and the court considered the deception practiced on the corporation to be in this category of offense. This reasoning is criticized in 13 Stan. L. Rev. 378, 380 (1961). Both Hooper and Pettit v. American Stock Exch., 217 F. Supp. 21 (S.D.N.Y. 1963), which also rejected the theory that corporations could not sue under rule $10 \mathrm{~b}-5$, pointed out that overvalued stock would be distributed to the public as a result of the deception and that it was within the intent of Congress to protect against this. Other courts have permitted the corporation to sue without showing that the public will be injured. Dembitzer v. First Republic Corp., CCH Fed. SEC. L. REP. I 91445 (S.D.N.Y. 1964); New Park Mining Co. v. Cranmer, 225 F. Supp. 261, 267 (S.D.N.Y. 1963); Dauphin Corp. v. Davis, 201 F. Supp. 479 (D. Del. 1962). Thus, injury to the public interest may be a sufficient, though not a necessary, ground for recovery.

79 The corporation's suit will be brought by shareholders since the directors cannot be expected to initiate an action against themselves. Since the corporation is a purchaser, there is some question as to the effect of $\S 12(2)$ of the Securities Act upon the action brought under rule 10b-5. Section 12(2) applies to all sellers who make a false representation by means of "prospectus or oral communication," which will normally be the case if the insider defrauds the other directors by misrepresenting a material fact. Some courts have perceived a conflict in the fact that the applicability of the two sections overlaps and have distinguished the application of the sections by requiring scienter under $10 \mathrm{~b}-5$. If the insider should omit to state a material fact, $\$ 12(2)$ would not apply and no conflict with rule $10 \mathrm{~b}-5$ would arise. Most courts have apparently ignored the conflict between the two sections or have allowed the buyer to sue under rule 10b-5. E.g., Ellis v. Carter, 291 F.2d 270 (9th Cir. 1961); Rosenberg v. Globe Aircraft Corp., 80 F. Supp. 123 (E.D. Pa. 1948). A few courts, however, have insisted that the buyer suing under rule 10b-5 allege fraud and the scienter which that action requires, in an attempt to differentiate the two remedies. Fischman v. Raytheon Mfg. Co., 188 F.2d 783 (2d Cir. 195̈1); Weber v. C.M.P. Corp., CCH FEd. SEC. L. REP. I 91539 (S.D.N.X. June 2, 1965); Trussel v. United Underwriters, Ltd., 228 F. Supp. 757 (D. Colo. 1964). Where the plaintiff is able to prove willful deception on the part of the insider, the difference in proof required by the two remedies will not be important. In 
It might be argued that if rule 10b-5 were applied to permit a corporation to recover for a fraudulent tender by its directors, there would be no limit to the internal affairs subject to scrutiny under rule $10 \mathrm{~b}-5 .{ }^{80}$ But the director's deception of the corporation by overvaluing his tendered stock is like the normal application of rule $10 \mathrm{~b}-5$ to an insider's nondisclosure affecting a security's value. A shareholder in this situation sues on behalf of the corporation injured by nondisclosure in purchasing its stock, and as such does more than merely enforce a fiduciary duty which exists independently of the transaction. The corporation's purchase of stock at an inflated price should be within the protection of rule $10 \mathrm{~b}-5^{81}$ since the corporation is deceived by an insider in the same manner as is any other purchaser. Supporting this position are cases holding that the issuance of stock by a corporation to an insider for insufficient consideration will support a suit on the corporation's behalf under rule $10 \mathrm{~b}-5$ even though the insider is guilty of a breach of fiduciary duty and mismanagement. ${ }^{82}$ Both the purchase and the sale by a corporation involve situations which Congress attempted to remedy by the securities acts: deception involving the valuation of securities which results in harm to investors.

cases where this proof is not available, there could be a difference depending upon the degree of scienter required under rule 10b-5. See Note, Proof of Scienter Necessary in a Private Suit Under SEC Antifraud Rule 10b-5, 63 Mrch. L. REv. 1070 (1965); Comment, Negligent Misrepresentation Under Rule 10b-5, 32 U. CHr. L. REv. 824 (1965); Comment, supra note 76, 74 YALE L.J. 658.

80 Although the language of $\S 10(\mathrm{~b})$ and rule $10 \mathrm{~b}-5$ seems to include any fraud "in connection with" a sale or purchase, the breadth of this statement has been limited by the desire to avoid the investigation of internal corporate disputes without more specific congressional authorization. See Fleischer, "Federal Corporation Law": An Assessment, 78 Harv. L. Rev. 1146, 1166 (1965); Leech, Transactions in Corporate Control, 104 U. PA. L. REv. 725, $831-35$ (1956). But see McClure v. Borne Chem. Co., 292 F.2d 824 (3d Cir.), cert. denied, 368 U.S. 939 (1961); Joseph, Civil Liability Under 10b-5-A Reply, 59 Nw. U.L. REv. 171, 178 (1964).

Furthermore, courts have not allowed recovery under rule $10 \mathrm{~b}-5$ to plaintiffs not parties to a transaction who merely seek to enforce a general fiduciary duty of the defendant. Birnbaum v. Newport Steel Corp., 193 F.2d 461 (2d Cir. 1952); Chashin v. Mencher, CCH FED. SEC. L. REP. ff 91551 (S.D.N.Y. June 10, 1965); Keers \& Co. v. American Steel \& Pump Corp., 234 F. Supp. 201 (S.D.N.Y. 1964); Kremer v. Selheimer, 215 F. Supp. 549 (E.D. Pa. 1963); Slavin v. Germantown Fire Ins. Co., 74 F. Supp. 876 (E.D. Pa. 1947). But see McManus v. Jessup \& Moore Paper Co., 5 S.E.C. Jud. Dec. 810 (E.D. Pa. 1948) (motion to dismiss denied where suit by minority shareholder against majority shareholders who sold their stock to third parties at a premium).

81 See New Park Mining Co. v. Cranmer, 225 F. Supp. 261, 267 (S.D.N.Y. 1963); 3 Loss 1770-71; Fleischer, supra note 80, at 1165 .

82 Ruckle v. Roto Am. Corp., 339 F.2d 24 (2d Cir. 1964); Hooper v. Mountain States Sec. Corp., 282 F.2d 195 (5th Cir. 1960), cert. denied, 365 U.S. 814 (1961); Kane v. Central Am. Mining \& Oil, Inc., 235 F. Supp. 559 (S.D.N.Y. 1964). 


\section{B. Transactions Involving Corporate Control}

The tender offer may be instigated by the directors or other insiders for the purpose of utilizing the corporation's funds to secure control. ${ }^{83}$ The tender offer may be aimed at eliminating a particular block of opposing stock or may be calculated to increase the insiders' share by decreasing the number of shares outstanding. The tender offer price would normally be set attractively high in order to induce the sale.

Two courts recently considered the effect of a corporate purchase to secure control for the directors; both O'Neill v. Maytag ${ }^{84}$ and Hoover v. Allen $^{85}$ dismissed derivative suits alleging that the directors failed to disclose that their purpose in authorizing the purchase was to strengthen their control. These decisions can be explained in terms of the courts' desire to limit the application of rule $10 \mathrm{~b}-5$ to requiring the disclosure necessary to enable shareholders to be aware of and to enforce their rights, and to relegate questions dealing more generally with the propriety of insiders' actions to state corporation law.

The Second Circuit in Maytag dismissed a derivative suit alleging that the directors had authorized the purchase of the company's stock from another corporation at a price above the market rate in order to eliminate the threat which this block of shares posed to their control. The court stated that there was a failure to allege facts "amounting to deception" and limited the scope of rule $10 \mathrm{~b}-5$ to cases where there is more than a mere breach of fiduciary duty, adding that rule $10 \mathrm{~b}-5$ does not impose "duties beyond that of honest disclosure." 86 If the court's rather confusing opinion intended to assert that rule $10 \mathrm{~b}-5$ is not violated because the corporation is not deceived when all directors have knowledge of the real purpose for paying more than the market rate, its reasoning appears fallacious. There is no indication that this position has any support in other decisions, and in fact the Second Circuit held only a few weeks before Maytag that although a majority of the directors had knowledge of the fraud, the shareholder might sue derivatively under rule $10 \mathrm{~b}-5 .{ }^{8 \pi}$ Neither logic nor common sense denies that a corporation can be defrauded even if all the

83 See Kessler, Share Repurchases Under Modern Corporation Laws, 28 FordHAM L. REv. $637,671-72$ (1960). This objective might be attained more covertly, as by having a subsidiary or affiliate corporation or a pension fund administered by the officers of the corporation make the purchase.

84339 F.2d 764 (2d Cir. 1964).

85241 F. Supp. 213 (S.D.N.Y. 1965).

80339 F.2d at 767 . The SEC as amicus curiae had urged that deception exists when directors purchase for an illicit purpose which is not disclosed to the shareholders. Brief for the SEC as Amicus Curiae, p. 14.

87 Ruckle v. Roto Am. Corp., 339 F.2d 24, 29 (2d Cir. 1964). 
directors are aware of the fraud, indeed that the directors themselves can defraud the corporation. ${ }^{88}$ If a majority of the directors or the entire board is involved ${ }^{89}$ in the illegal action, the corporation is deceived in the sense that those who ultimately bear its losses and who are in a position to seek redress of its injury are ignorant of the fraud.

It can be argued that an improper motive for the tender offer, such as using it to solidify control, should not be sufficient to create rule 10b-5 liability absent deception regarding the value of the security sold. ${ }^{90}$ But if there is deliberate pricing of a tender offer above the market price, whether for personal profit or to secure control, the policy of the securities acts would seem to demand that the corporation be allowed to recover. As noted previously, deception is present in such cases in the insider's omitting to disclose a material fact in connection with the corporation's purchase of its securities from tendering shareholders.

88 The directors' deception poses the conceptual problem of whether the corporation can deceive itself if the directors are regarded as being the "corporation" when they act. The court in Ruckle v. Roto Am. Corp., 339 F.2d 24 (2d Cir. 1964), disposed of this puzzle without difficulty. The fact that a majority of the directors were involved in the fraud was not permitted to circumvent the securities acts' policy of protecting investors. Referring to cases of embezzlement or conflict of interest, the court held that directors can indeed defraud the corporation. See also Kane v. Central Am. Mining \& Oil, Inc., 235 F. Supp. 559 (S.D.N.Y. 1964), and New Park Mining Co. v. Cranmer, 225 F. Supp. 261 (S.D.N.Y. 1963), holding controlling directors liable to the corporation under rule I0b-5 for breaches of fiduciary duty similar to that in Maytag. Neither court discussed the conceptual difficulty involved when the controlling directors deceive the corporation.

Furthermore, it is well-settled agency doctrine that its agents' knowledge will not be imputed to a corporation when they have a personal interest in concealing the knowledge. In addition, courts have employed the term "fraud" under circumstances similar to those in Maytag. Fraud in the concealment of facts has not been limited to those cases where some of the directors were unaware of the fraud. See Israels, Corporate Purchase of Its Own Shares-Are There New Overtones?, 50 CORNELL L.Q. 620, 626-27 (1965).

89 A defendant need not have been a party to the transaction to be liable under rule 10b-5. The privity requirement has been avoided in some cases by using a conspiracy theory. E.g., Pettit v. American Stock Exch., 217 F. Supp. 21 (S.D.N.Y. 1963). Other cases have simply dispensed with the requirement altogether. E.g., Miller v. Bargain City, 229 F. Supp. 33 (E.D. Pa. 1964); Freed v. Szabo Food Serv., Inc., CCH FED. SEc. L. REP. $\$ 91317$ (N.D. Ill. 1964); Cochrane v. Channing Corp., 211 F. Supp. 239, 243-44 (S.D.N.Y. 1962). In Freed, the court stated that relief will be granted if the plaintiff proves "that he has relied upon misleading statements uttered by the defendant concerning the securities in question; that he has purchased the securities from whatever source, relying upon these misleading statements; and that through such purchase he has suffered damage." Id. at 94363. This would appear to be a recognition of the tort implications of rule 10b-5 in that the defendant's ability to foresee the plaintiff's reliance on his misstatement or omission are key elements of liability.

90 See Fleischer, supra note 80, at 1165; Ruder, supra note 68, 59 Nw. U.L. REv. at 196206; Note, Securities Regulation-Rule 10b-5-A Federal Corporations Law?, 43 N.C.L. REv. 637, 644-47 (1965). 
Hoover $v$. Allen ${ }^{91}$ presented a slightly different issue that helps to delineate the scope of rule 10b-5. The plaintiff, who had not tendered his stock, brought a derivative suit alleging that the purpose of the offer was to ensure the insiders' control and that the insiders' omission to disclose material facts made it possible for them to set the tender price too low. The court distinguished purchases by a corporation at an excessive price and held that there was no derivative cause of action because the corporation could not be injured if it paid less than what the shares were worth. The court thus suggested that an insider's failure to disclose material facts which led to an overly high tender offer price would be grounds for a suit under rule 10b-5 on behalf of the corporation. Absent this misrepresentation, however, the mere failure to disclose that the directors' motive in authorizing the purchase was to secure control would not violate rule $10 \mathrm{~b}-5 .{ }^{92}$ The court felt that under these circumstances only the shareholders who had sold at the deceptively low price could obtain relief.

A more interesting question is whether relief can be obtained when the purpose of the purchase is to ensure control and the shareholders receive a fair price. In such a situation both the corporation and the tendering shareholders would have been deceived as to the motivation for authorizing the tender offer, but neither would have been injured financially. It would seem that the only possible infirmity in such a transaction is that the corporation is not authorized to purchase shares for such a purpose; this, however, is an issue outside the proper scope of rule $10 \mathrm{~b}-5$ and should be decided solely as a matter of state corporation law. Absent a misrepresentation of the value of securities, the purchase for control should not be considered fraud "in connection with" the purchase of securities. ${ }^{93}$ There would appear to be no reason for complaint by the selling shareholder in any case, since it must be evident to one selling that whatever the insiders' motivation, as a matter of fact the nontendering shareholders will own a greater percentage of a corporation with fewer liquid assets than they did before the

91241 F. Supp. 213 (S.D.N.Y. 1965).

$92 I d$, at $227-29$.

93 There is some indication that any breach of a fiduciary duty in any way connected with a security transaction may be challenged under rule 10b-5. See McClure v. Borne Chem. Co., 292 F.2d 824 (3d Cir.), cert. denied, 368 U.S. 939 (1961) (dictum); McManus v. Jessup \& Moore Paper Co., 5 S.E.C. Jud. Dec. 810 (E.D. Pa. 1948); Joseph, supra note 80, at 178. With the possible exception of these authorities, it appears that both the judiciary and the commentators are attempting to limit the scope of rule $10 \mathrm{~b}-5$ to situations having a close connection with securities transactions. Compare Ruckle v. Roto Am. Corp., 339 F.2d 24 (2d Cir. 1964), with O'Neill v. Maytag, 339 F.2d 764 (2d Cir. 1964). See Fleischer, supra note 80, at 1165-66; Ruder, supra note 68, 59 Nw. U.L. REv. at 186-87; 51 VA. L. REv. 508 (1965). 
tender. No grounds for recovery based on rule 10b-5 exist because the fact which was not disclosed was not material to a decision whether or not to sell.

\section{The Purchase of Securities Having Dividends in Arrears}

The distinction between internal mismanagement and fraud in connection with securities transactions is also reflected in the use of an offer to purchase preferred stock which has unpaid accumulated dividends. The passing of dividends will drive down the market price of the stock, resulting in a tender price lower than it would have been if the dividends had been paid.94 Tendering his shares also means that the shareholder loses the possibility of collecting his arrears. Such a tender offer frees for distribution to the remaining shareholders cash which might have been used to pay dividend arrears. Since rarely will the type of stock normally accruing dividends be held by the controlling shareholders, they may be greatly tempted to utilize the repurchase technique.

The applicability of rule $10 \mathrm{~b}-5$ to this situation is illustrated by Cochrane $v$. Channing Corp. ${ }^{95}$ where the plaintiff alleged that he was induced to sell his preferred stock by the passing of dividends which lowered its market price. The court ruled that even absent an affirmative misrepresentation by the controlling shareholder, the latter was guilty of "employing a device to defraud" and "engaging in a course of business which operates as a fraud upon the seller" of securities. ${ }^{96}$ The failure to disclose the true reason for passing the dividends constituted nondisclosure of a material fact in connection with the purchase of the securities.

If a shareholder can prove a conscious effort to affect the price by the passing of dividends, a scheme to defraud and a misrepresentation of a material fact should be found. The nontendering insiders who benefit from this misrepresentation are like those who fail to disclose the true value of the stock in order to increase their share in the corporation by inducing others to tender their shares at too low a price. The proper function of rule $10 \mathrm{~b}-5$ is to require that all facts material to the transaction be revealed so as to permit an informed judgment by both parties. If the real purpose for passing the dividends is disclosed, the

94 See Note, Purchase by a Corporation of Its Own Preferred Shares With Dividends in Arrears, 14 U. CHI. L. REv. 66, 67 (1946).

95211 F. Supp. 239 (S.D.N.Y. 1962).

96 Id. at 243. The court in Cochrane allowed the plaintiff to recover even though he did not sell to the defendants. The implications of this holding for the corporate tender offer are important: any person who relies on the statements made in connection with the offer and sells his stock on the market may have an action against the corporation. 
shareholder can judge for himself the relative benefits of tendering, holding his stock in hopes of future dividends and price rises, or pursuing his remedy in state courts to force the payment of dividends if such an action is possible.

The SEC, however, seems to wish to go further than this. It has stated, respecting its regulation of closed-end investment companies, that a purchase of shares with arrearages will violate rule 10b-5 "even though all material facts are disclosed" if "substantial earnings are available for [the purpose of paying off the arrears]." 97 Such a position is highly problematical, especially with respect to determining when "substantial earnings are available" for this purpose. Indeed, it is not at all clear what role the judiciary should play in supervising management's control over capital..$^{98}$ It would appear that absent proof of an intent to drive down the price of the preferred stock before the tender offer, the corporation's purchase of preferred stock with arrears should be outside the scope of rule $10 \mathrm{~b}-5$ and the propriety of management's decision to pass dividends should be left to state corporation law.99 Rule 10b-5 would seem to be satisfied if all facts surrounding the transaction are disclosed to the shareholders; prohibiting purchases merely because surplus is available to pay off arrears would be an unwarranted extension of the rule.

\section{Conclusion}

One solution to the problems created by the tender offer would be SEG supervision of the information distributed to shareholders. A

97 Investment Company Act Release No. 3548, Oct. 3, 1962. The SEC has taken the position that fraudulent conduct may occur even if there is full disclosure. See Cohen \&: Rabin, Broker-Dealer Selling Practice Standards: The Importance of Administrative Adjudication in Their Development, 29 LAw \& CoNTEMP. PROB. 691,703 (1964); Frohling, The Promoter and Rule 106-5; Bases for Accountability, 48 CoRNeLl L.Q. 274, 306-07 (1963).

88 Courts applying state law are reluctant to force the payment of dividends by secondguessing management. See Johnson v. Fuller, 121 F.2d 618, 620 (8d Cir. 1941); Geller v. Transamerica Corp., 53 F. Supp. 625 (D. Del. 1943). The possibility of state remedies for the seller is suggested in Note, supra note $94,14 \mathrm{U}$. CHI. L. REv. at 71.

99 If the tender offer were made to another class of shareholders, the shareholder with accumulated dividends might attempt to challenge the transaction under rule $10 \mathrm{~b}-5$. The requirement that the plaintiff be a party to the transaction would seem to bar such a suit. Birnbaum v. Newport Steel Corp., 193 F.2d 461 (2d Cir.), cert. denied, 343 U.S. 956 (1952). The only case to apply a different rule is McManus v. Jessup \& Moore Paper Co., 5 S.E.C. Jud. Dec. 810 (E.D. Pa. 1948), although in J. I. Case Co. v. Borak, 377 U.S. 426 (1964), a shareholder was allowed to enforce the proxy rules even though he was not deceived by the misleading statement. The Court stated that that plaintiff could enforce the rules by a derivative or an individual suit. One commentator forecasts the eventual overruling of Birnbaum. Ruder, supra note 68, 59 Nw. U.X. REv. at 205. Of course, even if the Birnbaum requirement could be overcome, it is not clear what fraud or nondisclosure the plaintiff could allege. 
congressional amendment of the Securities Exchange Act might require that a registration statement be submitted and a prospectus be sent to each shareholder. Detailed requirements for such statements might eliminate many of the violations of rule $10 \mathrm{~b}-5$ and discourage violations of state law and self-dealing generally while establishing guidelines by which corporations could determine what constitutes a material fact. ${ }^{100}$ The SEC presently regulates in this manner the purchases by investment companies of their own securities. ${ }^{101}$

Such a registration statement might also be required by an SEC regulation under the present section $10(\mathrm{~b})$. It is difficult to justify such a regulation, however, in terms of the congressional grant of authority to the SEC in the securities acts. ${ }^{102}$ Congress seems not to have intended to authorize a "reverse prospectus" under section 10(b), since the Securities Act of 1933 expressly delineated the requirements for registration statements which accompany offers to sell and authorized the SEG to draft supplementary rules. ${ }^{103}$ The grant of specific power to regulate corporate purchases under the Investment Company Act $^{104}$ and the Holding Company Act $^{105}$ would appear to negate any congressional intent that the SEC exercise this power over other corporations. The general grant of power in section 10(b), interpreted in light of its purpose to prevent fraudulent transactions, suggests that Congress intended only that the SEC define the fraudulent practices prohibited by the section. ${ }^{106}$ In addition, although the Commission

100 Such guidelines would avoid the pressure on management to refrain from acting altogether, which some commentators fear might result from expanding liability without establishing clear standards of liability. See Kennedy \& Wander, supra note 64, at 1067; Note, SEC Action Against Fraudulent Purchasers of Securities, 59 HARv. L. Rev. 769, 778 (1946).

10154 Stat. 825 (1940), 15 U.S.C. § 80a-23(c) (1964); see 17 C.F.R. § 270.23c-1(a)(6) (1949). 102 Furthermore, the SEC's resources may already be so overburdened that the Com. mission could not handle the job as a practical matter. Cf. J. I. Case Co. v. Borak, 377 U.S. 426, 432 (1964); Cary, Book Review, 75 HaRv. L. REv. 857, 861 (1962), suggesting that the private enforcement of the Securities Acts is justified by the Commission's inability to enforce them.

10348 Stat. 78 (1933), 15 U.S.C. $₹ 77 \mathrm{~g}$ (1964). Section 5(c) of the Securities Act applies these requirements to "offers to buy" as well as offers to sell since a registration statement is required for both transactions. This could serve as a basis for SEC supervision of tender offers but for the fact that the legislative history of the section indicates that offers to buy were included "solely for the purpose of preventing dealers from making offers to buy from underwriters . . . before the filing of the registration statement." 1 Loss 212-13 (emphasis in original). See S. REP. No. 1036, 83d Cong., 2d Sess. 15 (1954); H.R. REP. No. 1542, 83d Cong., $2 d$ Sess. 24 (1954). Thus, the statute has no application to corporate offers to purchase. 104 See note 101 supra.

10549 Stat. 838 (1935), 15 U.S.C. $\$ 79$ (1963); 17 C.F.R. $\S 250.23$ (c)-(e) (1949).

106 Under the terms of $\S 10(\mathrm{~b})$ there would be no sanction for the failure to register the tender offer if there was full disclosure. In contrast, $\S 5$ of the Securities Act makes it illegal not to register before the offer to sell. 48 Stat. 77 (1933), 15 U.S.C. $\$ 77$ (e) (1964). 
recently extended its jurisdiction under section 5 of the Securities Act by regulation after extensive hearings and study, ${ }^{107}$ this extension was clearly authorized under the broad congressional grant of jurisdiction in section 5. Section 10(b) of the Securities Exchange Act contains no such authorization. ${ }^{108}$ Thus, it can be argued persuasively that the SEC should not regulate all tender offers without express congressional authorization. ${ }^{109}$

Many problems relating to corporate purchases are common to the general area of insiders' transactions, and discussion of the scope and requirements of rule $10 \mathrm{~b}-5$ should consider the problem in this broader perspective. ${ }^{110}$ Judicial determinations of the burden of disclosure under rule $10 \mathrm{~b}-5$ are necessarily $a d$ hoc and to date have inadequately defined "materiality" and the scope of rule 10b-5 liability. On the other hand, SEC regulation in cases where congressional intent does not justify judicial interference does not seem proper. Until Congress elaborates on the standards required for liability under rule $10 \mathrm{~b}-5$, these standards must be supplied by courts for the guidance of both shareholders and corporate officials.

Criteria have been suggested above for the judicial determination of the burden of disclosure under rule $10 \mathrm{~b}-5$ and for the limitation of the scope of rule $10 \mathrm{~b}-5$ respecting claims of corporate mismanagement not involving deception in the purchase or sale of securities. A corporation purchasing shares should be required to disclose all facts necessary to an informed judgment by shareholders whether to tender their shares at the offer price, but the company should not be required to meet unrealistic disclosure demands. In addition, nontendering shareholders may be deceived by insiders who manipulate the tender offer for purposes of personal gain and control. The policy of rule $10 \mathrm{~b}-5$ requires the disclosure of those facts necessary for such shareholders to

107 Report of Special Study of Securities Market of the Securities and Exchange Commission, H.R. Doc. No. 95, Parts 1-5, 88th Cong., 1st Sess. (1963).

108 On the other hand, the Commission requires proxy statements and regulates their contents pursuant to a grant of power identical to that in $\S 10(\mathrm{~b})$ of the Securities Exchange Act. Section 14 of the Securities Exchange Act provides: "It shall be unlawful for any person .... in contravention of such rules and regulations as the Commission may prescribe as necessary or appropriate in the public interest or for the protection of investors, to solicit or to permit the use of his name to solicit any proxy . ..." See 17 C.F.R. \$ 240.14a-3 (1937). The Commission might similarly require statements of material facts to be submitted for its examination before a tender offer.

109 Senator Williams of New Jersey has introduced a bill which would require compliance with disclosure requirements promulgated by the SEC in the case of a tender offer for equity securities where the offeror was the issuer of the security or one who would own more than $5 \%$ of the security after the tender. S. 2731, 89th Cong., 1st Sess. (1965).

110 See Kaplan, Corporation Law and Securities Regulation, 18 Bus. LAw. 868, 872-73 (1963); Ruder, supra note 68, 59 Nw. U.L. REv. at 206-07. 
evaluate the purchased securities intelligently so that they can assert their rights effectively. However, suits should be dismissed when the mismanagement is not closely related to a violation of disclosure requirements in connection with a securities transaction, because the sole purpose of rule $10 \mathrm{~b}-5$ is to force full disclosure. 